УДК 35.182

DOI: https://doi.org/10.26642/jen-2021-2(96)-77-84

Д.О. Грицишен, д.е.н., проф. С.В. Свірко, д.е.н., проф.

І.В. Супрунова, к.е.н., доц.

Державний університет «Житомирська політехніка»

\title{
Інституалізація державної фінансово-контрольної діяльності як інструмента бюджетної безпеки країни
}

\begin{abstract}
Реформування механізму державного управління в України в умовах сукупної дії ризиків внутрішнього та зовнішнього характеру потребує зосередження уваги на бюджетній безпеці. Уконтексті цього розбудова державної фінансово-контрольної діяльності через ії інституалізацію є важливим фактором досягнення останньої. 3 метою реалізації цього завдання в роботі запропоновано авторську дефініцію «інституалізація державної фінансово-контрольної діяльності», під якою пропонується розуміти процес ідентифікаиії відповідних інститутів, формалізації та систематизації фундаментальних положень (об’єкт, мета, принциипи, функції, завдання, форми, норми) такої діяльності иих інститутів зокрема $і$ в иілому або в контексті відповідного фокусного запиту. Опрацювання чинного нормативно-правового поля $i$ наукових підходів дозволило ідентифікувати та систематизувати інституційні засади щзодо кожного $з$ виокремлених інститутів такої діяльності, а саме: Рахункової палати Украӥни, Державноі аудиторської служби України, Державної податкової служби Украӥни, Державної митноі служби Украӥни, Державної казначейської служби Украӥни, Державної служби фінансового моніторингу України. Щодо кожного з них виокремлено мету, функиії, завдання, повноваження, форми контрольної діяльності та нормативне забезпечення в контексті фокусного запиту сприяння досягнення бюджетної безпеки. Це дозволило згенерувати матрищю інституалізаџії власне державної фінансово-контрольної діяльності як інструмента досягнення бюджетної безпеки, яка містить мету, предмет, об'єкти, суб'єкти, принципи, функиії, завдання, форми та норми. Ї̈ реалізація сприятиме оздоровленню не тільки економіки нашого суспільства, а й його морально-духовної сфери, а синергічний ефект таких зрушень забезпечить отримання реальних дієвих результатів на шляху реалізації Україною цілей сталого розвитку.
\end{abstract}

Ключові слова: інституалізація; державна фінансово-контрольна діяльність; бюджетна безпека.

Актуальність теми. Подальша розбудова вітчизняної економічної моделі здійснюється паралельно 3 формуванням принципово інших механізмів державного управління на тлі досить складної політичної, економічної та соціальної ситуації. За цих умов посилюється напруження в системі державних фінансів, яка досить довгий час перебуває в кризовому стані. Одним 3 найважливіших індикаторів стабілізації системи державних фінансів $є$ бюджетна безпека, яка як елемент економічної безпеки країни являє собою «...стан забезпечення платоспроможності та фінансової стійкості державних фінансів, що надає можливість органам державної влади максимально ефективно виконувати покладені на них функції» [1].

Питання бюджетної безпеки набуло свого активного розвитку в останні десятиріччя через сукупність зовнішніх та внутрішніх факторів, що все більше впливають на систему державних фінансів, у тому числі на тлі процесів глобалізації. Зауважимо, що стабільність та розвиток системи державних фінансів у нашій країні, що вирізняється значним за розміром бюджетним сектором, є головною умовою розвитку української державності в цілому. Оскільки однією з основних функцій управління є контроль, то очевидно сприянню досягнення відповідного рівня бюджетної безпеки передусім має слугувати державна фінансово-контрольно діяльність, інституціональними органом якої є в нашій країні Рахункова палата України, а також відповідні органи в компетенції Міністерства фінансів України: Державна аудиторська служба України, Державна податкова служба України, Державна митна служба України, Державна служба фінансового моніторингу, Державна казначейська служба України.

Аналіз останніх досліджень і публікацій. Проблематикою бюджетної безпеки у різні часи опікувались такі українські вчені: О.Барановський, О.Вишневська, О.Христенко, М.Срмошенко, І.Король, О.Лемішко, А.Полторак, О.Підхомний, Н.Прокопенко, Н.Сіренко, О.Тарасова, К.Захожай, С.Фролов та інші автори. Дослідженню питань державного контролю / аудиту присвятили свої праці такі вітчизняні вчені: І.Дрозд, О.Дорошенко, С.Бардаш, О.Шевчук, О.Редько, І.Чумакова, С.Калюга, Н.Обрушна, Н.Фукс, В.Уложенко, І.Чугунов, В.Федосов, Ю.Слободяник, Т.Косова, В.Шевченко, О.Койчева, В.Невідомий, Л.Гуцаленко, В.Пихоцький, В.Максімова, І.Стефанюк, В.Симоненко, Л.Чижевська, Т.Бутинець та інші. У працях вказаних вчених розглядалася низка питань щодо теоретичних положень і практичних підходів до бюджетної безпеки та державного фінансового 
контролю (аудиту) відповідно. Проте семантикою складної словникової конструкції «державна фінансово-контрольна діяльність щодо гарантування бюджетної безпеки» жоден з авторів не переймався.

Метою статті є формування інституційних засад державної фінансово-контрольної діяльності в контексті функціонального спектру бюджетної безпеки.

Викладення основного матеріалу. Нагадаємо, що в цілому під інституалізацією розуміють «...процес визначення і закріплення соціальних норм, правил, статусів і ролей, приведення їх у систему, здатну діяти у напрямі задоволення деякої суспільної потреби. В науці - етап, коли процес продукування нею знань стає методологічно упорядкованим, а також залежним від організаційних форм, в яких він набуває якостей спеціалізованої суспільної практики; становлення різноманітних комунікативних органів науки - наукових інституцій, що відбувається в ході перетворення наукових досліджень у спеціалізовану суспільну діяльність» [7]. В контексті об'єктної спрямованості дослідження пропонується під «інституалізацією державної фінансово-контрольної діяльності розуміти процес ідентифікації відповідних інститутів, формалізації та систематизації фундаментальних положень (об'єкт, мета, принципи, функції, завдання, форми, норми) такої діяльності цих інститутів зокрема та в цілому або в контексті відповідного фокусного запиту» [27]. Розглянемо послідовно кожний із таких інститутів саме 3 позиції формування інституційних засад їх діяльності у сфері запобігання економічній злочинності.

Вищим органом аудиту в Україні є Рахункова палата, яка згідно з Законом України «Про Рахункову палату» являє собою державний колегіальний орган, що від імені Верховної Ради України (якій вона підзвітна та регулярно інформує про результати своєї роботи) здійснює контроль за надходженням коштів до Державного бюджету України та їх використанням [8]. У своїй діяльності Рахункова палата палата керується Конституцією України, вказаним вище Законом та іншими нормативно-правовими актами України. Принципами діяльності Рахункової палати України $є$ принципи законності, незалежності, об'єктивності, безсторонності, гласності та неупередженості. Рахункова палата наділена певними повноваженнями, що реалізуються шляхом державного зовнішнього фінансового контролю (аудиту) (що містить фінансовий аудит, аудит ефективності, експертизу, аналіз та інші контрольні заходи) за відповідними спрямуваннями [8]. Аналіз широкого кола нормативних позиції вказує на відсутність ідентифікованих фундаментальних положень цього інституту державної фінансовоконтрольної діяльності та систематизації останніх у контексті обраного вектора дослідження. Опрацювання нормативно-правового поля діяльності Рахункової палати, результатів наукових досліджень i думок фахівців призвів до формування такої сукупності відправних положень інституалізації державної фінансово-контрольної діяльності в контексті бюджетної безпеки щодо Рахункової палата як первинного інституту відповідної діяльності [7-11, 27]:

- $\quad$ мета - сприяння досягненню бюджетної безпеки країни через реалізацію сукупності профільних функцій, завдань та повноважень;

- функції - контрольна, захисна, забезпечувальна, інформаційна;

- завдання - проведення якісних незалежних професійних компетентних контрольних заходів щодо державних фінансів та майна, що перебуває у державній власності; забезпечення упередження та виявлення фактів економічних зловживань і кримінальних дій щодо державних фінансів та майна, що перебуває у державній власності, задля захисту прав держави, комунальних громад, юридичних та фізичних осіб; сприяння досягненню відповідного рівня платоспроможності та фінансової стійкості державних фінансів; надання достовірної своєчасної інформації до відповідних правоохоронних органів;

- повноваження - широкий спектр повноважень в межах профільного чинного законодавства;

- $\quad$ форми контрольної діяльності - фінансовий аудит, аудит ефективності, експертиза, аналіз та інші контрольні заходи;

- нормативно-правове забезпечення діяльності - Конституція України і відповідні рішення Конституційного Суду, Бюджетний кодекс України, Кодекс України про адміністративні правопорушення, Кримінальний кодекс України, Закон України «Про Рахункову палату», Закон України «Про основні засади здійснення державного фінансового контролю в Україні», Укази Президента тощо.

Згідно з Постановою Кабінету Міністрів України № 375 «забезпеченням формування та реалізації державної політики у сфері контролю за дотриманням бюджетного законодавства, державного фінансового контролю, державного внутрішнього фінансового контролю, казначейського обслуговування бюджетних коштів, коштів клієнтів відповідно до законодавства, запобіганням та протидії легалізації (відмиванню) доходів, одержаних злочинним шляхом, фінансуванню тероризму та фінансуванню розповсюдження зброї масового знищення» переймається Міністерство фінансів України [12]. Втім, фактичну реалізацію означених завдань здійснюють відповідні центральні органи виконавчої влади в компетенції Міністерства фінансів України.

Першим з таких органів є Державна аудиторська служба України, яка призвана: реалізовувати державну політику у сфері державного фінансового контролю; вносити на розгляд Міністра фінансів пропозиції щодо забезпечення формування державної політики у сфері державного фінансового контролю; здійснювати державний фінансовий контроль, спрямований на оцінку ефективного, 
законного, цільового, результативного використання та збереження державних фінансових ресурсів і майна, досягнення економії бюджетних коштів; надавати у передбачених законом випадках адміністративні послуги [12]. Відповідно до покладених завдань, останній орган виконавчої влади здійснює контрольні заходи у формі: державного фінансового аудиту, інспектування (ревізії), перевірки та моніторингу закупівель у межах встановлених повноважень. Аналіз, змістовне узагальнення та інформаційна сепарація нормативно-правових актів, що регулюють діяльність Державної аудиторської служби України уможливили формування такої сукупності відправних положень інституалізації державної фінансово-контрольної діяльності у фокусі бюджетної безпеки щодо інституціонального суб’єкта - Державної аудиторської служби України [12-14, 27]:

- $\quad$ мета - сприяння досягненню бюджетної безпеки країни через реалізацію сукупності профільних функцій, завдань та повноважень;

- функції - контрольна, захисна, забезпечувальна, інформаційна;

- завдання - проведення якісних незалежних професійних компетентних контрольних заходів у сфері фінансових та майнових відносин; забезпечення виявлення та подальше упередження фактів економічних зловживань і кримінальних дій у сфері фінансових та майнових відносин з метою захисту прав держави, комунальних громад, юридичних і фізичних осіб; сприяння досягненню відповідного рівня платоспроможності та фінансової стійкості державних фінансів; надання достовірної своєчасної інформації до відповідних правоохоронних органів;

- повноваження - широкий спектр повноважень у межах профільного чинного законодавства;

- форми контрольної діяльності - державний фінансовий аудит, інспектування (ревізії), перевірки та моніторинг закупівель;

- нормативно-правове забезпечення діяльності - Конституція України і відповідні рішення Конституційного Суду, Бюджетний кодекс України, Кодекс України про адміністративні правопорушення, Кримінальний кодекс України, Закон України «Про основні засади здійснення державного фінансового контролю в Україні», Укази Президента, Постанови Кабінету Міністрів, Накази Міністерства фінансів України тощо.

Іншим інституціональним суб'єктом державної фінансово-контрольної діяльності є Державна податкова служба України, яка згідно з Постановою Кабінету Міністрів України № 227 реалізує державну податкову політику, здійснює в межах передбачених законом повноважень «контроль за надходженням до бюджетів та державних цільових фондів податків, зборів, платежів, державної політики у сфері контролю за виробництвом та обігом спирту, алкогольних напоїв, тютюнових виробів, пального, державної політики з адміністрування єдиного внеску, державної політики у сфері контролю за своєчасністю здійснення розрахунків в іноземній валюті в установлений законом строк, дотриманням порядку проведення готівкових розрахунків за товари (послуги), проведення розрахункових операцій, а також за наявністю ліцензій на провадження видів господарської діяльності, що підлягають ліцензуванню відповідно до закону; а також внесення на розгляд Міністра фінансів пропозицій щодо забезпечення всіх вищевказаних заходів» [15]. Дослідження положень нормативно-правових актів регуляторної сфери дії щодо вказаного органу дозволило сформувати таку сукупність відправних положень інституалізації державної фінансово-контрольної діяльності Державної податкової служби України в контексті запиту механізму гарантування бюджетної безпеки $[15,16,27]$ :

- $\quad$ мета - сприяння досягненню бюджетної безпеки країни через реалізацію сукупності профільних функцій, завдань та повноважень;

- функції - контрольна, захисна, забезпечувальна, інформаційна;

- Завдання - проведення якісних незалежних професійних компетентних податкових контрольних заходів за: надходженням до бюджетів та державних цільових фондів податків, зборів, платежів, внесків; виробництвом та обігом спирту, алкогольних напоїв, тютюнових виробів, пального; своєчасністю здійснення розрахунків в іноземній валюті в установлений законом строк; дотриманням порядку проведення готівкових розрахунків за товари (послуги). А також проведення розрахункових операцій; забезпечення упередження та виявлення фактів економічних зловживань і кримінальних дій у сфері податкових та інших відносин, що знаходяться в компетенції Державної податкової служби України, з метою захисту інтересів держави; сприяння досягненню відповідного рівня платоспроможності та фінансової стійкості державних фінансів; надання достовірної своєчасної інформації до відповідних правоохоронних органів;

- повноваження - широкий спектр повноважень в межах профільного чинного законодавства;

- форми контрольної діяльності - податковий контроль та інші контрольні заходи;

- нормативно-правове забезпечення діяльності - Конституція України і відповідні рішення Конституційного Суду, Податковий кодекс України, Бюджетний кодекс України, Кодекс України про адміністративні правопорушення, Кримінальний кодекс України, Укази Президента, Постанови Кабінету Міністрів, Накази Міністерства фінансів України тощо. 
Наступним важливим суб'єктом державної фінансово-контрольної діяльності є Державна митна служба України, яка забезпечує реалізацію: державної митної політики, зокрема забезпечення митної безпеки та захисту митних інтересів України і створення сприятливих умов для розвитку зовнішньоекономічної діяльності, збереження належного балансу між митним контролем і спрощенням законної торгівлі; державної політики у сфері боротьби з правопорушеннями під час застосування законодавства 3 питань митної справи, запобігання та протидії контрабанді, боротьби з порушеннями митних правил; здійснює внесення пропозицій щодо забезпечення формування державної митної політики на розгляд Міністра фінансів [15]. Вивчення змістовних позицій нормативно-правових актів з регулювання діяльності вказаного центрального органу виконавчої влади забезпечило формування такої сукупності відправних положень інституалізації державної фінансово-контрольної діяльності Державної митної служби України, аспектно щодо сприяння досягнення відповідного рівня бюджетної безпеки $[15,17,27]$ :

- $\quad$ мета - сприяння досягненню бюджетної безпеки країни через реалізацію сукупності профільних функцій, завдань та повноважень;

- $\quad$ функції - контрольна, захисна, забезпечувальна, інформаційна;

- завдання - проведення якісних незалежних професійних компетентних митних контрольних заходів 3 метою боротьби 3 правопорушеннями під час застосування законодавства 3 питань митної справи, запобігання та протидії контрабанді, боротьби з порушеннями митних правил; забезпечення упередження та виявлення фактів економічних зловживань і кримінальних дій у сфері митних та інших відносин, що знаходяться в компетенції Державної митної служби України з метою захисту інтересів держави; сприяння досягненню відповідного рівня платоспроможності та фінансової стійкості державних фінансів; надання достовірної своєчасної інформації до відповідних правоохоронних органів;

- $\quad$ повноваження - широкий спектр повноважень в межах профільного чинного законодавства;

- форми контрольної діяльності - митний контроль та інші контрольні заходи;

- нормативно-правове забезпечення діяльності - Конституція України і відповідні рішення Конституційного Суду, Митний кодекс України, Податковий кодекс України, Бюджетний кодекс України, Кодекс України про адміністративні правопорушення, Кримінальний кодекс України, Укази Президента, Постанови Кабінету Міністрів, Накази Міністерства фінансів України тощо.

Державна казначейська служба України є опосередкованим суб'єктом державної фінансовоконтрольної діяльності, оскільки згідно з відповідним нормативно-правовим забезпеченням до сфери ії завдань належать [18]: реалізація державної політики у сферах казначейського обслуговування бюджетних коштів, коштів клієнтів відповідно до законодавства, бухгалтерського обліку виконання бюджетів; внесення на розгляд Міністра фінансів пропозицій щодо забезпечення формування державної політики у зазначених сферах. Втім, певні фінансово-контрольні повноваження за Державною казначейською службою закріплені перед усім Бюджетним кодексом України та іншими нормативними актами: зокрема йдеться про реєстрацію та облік зобов'язань розпорядників і одержувачів бюджетних кошів [18-22]. Отже, розгляд Державної казначейської служби України в якості відповідного інституту державної фінансово-контрольної діяльності є правомірним.

Опрацьовуючи інституційні засади державної фінансово-контрольної діяльності у фокусі гарантування бюджетної безпеки у форматі діяльності Державної казначейської служби України, наголосимо на таких основних вже відомих попередньо структурних положеннях $[9,18,27]$ :

- $\quad$ мета - сприяння досягненню бюджетної безпеки країни через реалізацію сукупності профільних функцій, завдань та повноважень;

- функції - контрольна, захисна, забезпечувальна, інформаційна;

- завдання - проведення якісних незалежних професійних компетентних казначейських контрольних заходів у межах казначейської системи обслуговування бюджетів; сприяння виявленню та подальшому упередженню фактів економічних зловживань і кримінальних дій в межах процесу казначейського обслуговування бюджетів 3 метою захисту інтересів держави; сприяння досягненню відповідного рівня платоспроможності та фінансової стійкості державних фінансів; надання достовірної своєчасної інформації до відповідних органів;

- повноваження - широкий спектр повноважень в межах профільного чинного законодавства;

- орми контрольної діяльності - казначейський контроль та інші контрольні заходи;

- нормативно-правове забезпечення діяльності - Конституція України і відповідні рішення Конституційного Суду, Бюджетний кодекс України, Кодекс України про адміністративні правопорушення, Кримінальний кодекс України, Укази Президента, Постанови Кабінету Міністрів, Накази Міністерства фінансів України тощо.

Останнім за хронологією утворення є специфічний суб’єкт державної фінансово-контрольної діяльності - Державна служба фінансового моніторингу, яка [23]: реалізує державну політику у сфері запобігання та протидії легалізації (відмиванню) доходів, одержаних злочинним шляхом, фінансуванню тероризму та фінансуванню розповсюдження зброї масового знищення; вносить на розгляд Міністра фінансів пропозиції щодо забезпечення формування державної політики у сфері запобігання та протидії 
легалізації (відмиванню) доходів, одержаних злочинним шляхом, фінансуванню тероризму та фінансуванню розповсюдження зброї масового знищення; збирає, обробляє та проводить аналіз (операційний i стратегічний) інформації про фінансові операції, що підлягають фінансовому моніторингу, інші фінансові операції, або інформації, що може бути пов'язана 3 підозрою в легалізації (відмиванні) доходів, одержаних злочинним шляхом, або фінансуванні тероризму чи фінансуванні розповсюдження зброї масового знищення; забезпечує функціонування та розвиток єдиної інформаційної системи у сфері запобігання та протидії легалізації (відмиванню) доходів, одержаних злочинним шляхом, фінансуванню тероризму та фінансуванню розповсюдження зброї масового знищення; проводить національну оцінки ризиків; налагоджує співпрацю, взаємодію та інформаційний обмін 3 державними органами, Національним банком, компетентними органами іноземних держав та міжнародними організаціями у сфері запобігання та протидії легалізації (відмиванню) доходів, одержаних злочинним шляхом, фінансуванню тероризму та фінансуванню розповсюдження зброї масового знищення; забезпечує в установленому порядку представництва України в міжнародних організаціях 3 питань запобігання та протидії легалізації (відмиванню) доходів, одержаних злочинним шляхом, фінансуванню тероризму та фінансуванню розповсюдження зброї масового знищення. Аналіз функціональних напрямів та особливостей діяльності Державної служби фінансового моніторингу дозволив виокремити такі інституційні засади державної фінансово-контрольної діяльності щодо гарантування бюджетної безпеки в діяльнісному сегменті вказаного вище органу виконавчої влади [23, 24, 27]:

- $\quad$ мета - сприяння досягнення бюджетної безпеки країни через реалізацію сукупності профільних функцій, завдань та повноважень;

- ункції - забезпечувальна, захисна, аналітична, інформаційна;

- $\quad$ завдання - забезпечення проведення якісних незалежних професійних компетентних контрольних заходів суб'єктами первинного фінансового моніторингу; сприяння виявленню та упередженню фактів економічних зловживань і кримінальних дій у межах різних економічних транзакцій 3 метою захисту інтересів держави та зміцненню іiі економічної безпеки; сприяння досягненню відповідного рівня платоспроможності та фінансової стійкості державних фінансів; реалізація аналітичних механізмів обробки інформації про фінансові операції, що підлягають фінансовому моніторингу та ііі узагальнення; надання достовірної своєчасної інформації до відповідних органів;

- $\quad$ повноваження - широкий спектр повноважень в межах профільного чинного законодавства;

- форми контрольної діяльності - фінансовий моніторинг та інші контрольні заходи;

- нормативно правове забезпечення діяльності - Конституція України і відповідні рішення Конституційного Суду, Бюджетний кодекс України, Кодекс України про адміністративні правопорушення, Кримінальний кодекс України, Закон України «Про запобігання та протидію легалізації (відмиванню) доходів, одержаних злочинним шляхом, фінансуванню тероризму та фінансуванню розповсюдження зброї масового знищення», Укази Президента, Постанови Кабінету Міністрів, Накази Міністерства фінансів України тощо.

Презентовані інституціональні засади діяльності відповідних інститутів державної фінансовоконтрольної діяльності в контексті адресного запиту щодо забезпечення бюджетної безпеки дозволяють генерувати матрицю інституалізації власне фінансово-контрольної діяльності як інструмента досягнення бюджетної безпеки (табл. 1) [1-27].

Таблиия 1

Матриця інституалізації фінансово-контрольної діяльності як інструмента бюджетної безпеки

\begin{tabular}{|c|l|}
\hline Каркасні елементи & \multicolumn{1}{|c|}{ Характеристика } \\
\hline 1 & \multicolumn{1}{|c|}{2} \\
\hline Мета & $\begin{array}{l}\text { Сприянн досягненню бюджетної безпеки країни через реалізацію сукупності } \\
\text { профільних функцій, завдань та повноважень у сфері фінансових та майнових, } \\
\text { податкових та митних, бюджетних відносин }\end{array}$ \\
\hline Предмет & Фінансові, майнові, податкові, митні, бюджетні відносини \\
\hline Об'єкти & $\begin{array}{l}\text { Інституціональні одиниці секторів: фінансових і нефінансових корпорацій, загального } \\
\text { державного управління, домашніх господарств, некомерційних організацій }\end{array}$ \\
\hline \multirow{2}{*}{ Суб’єкти } & $\begin{array}{l}\text { Рахункова палата України та відповідні органи в компетенції Міністерства фінансів } \\
\text { України: Державна аудиторська служба України, Державна податкова служба України, } \\
\text { Державна митна служба України, Державна казначейська служба України, Державна } \\
\text { служба фінансового моніторингу, суб'єкти первинного фінансового моніторингу }\end{array}$ \\
\hline Принципи & $\begin{array}{l}\text { Законність, об'єктивність, системність, синергізм, єдність цілей, розподіл компетенцій, } \\
\text { самостійність, систематичність, регулярність, оперативність, дієвість, масовість та } \\
\text { вибірковість, соціально-економічна спрямованість, відкритість та публічність, } \\
\text { плановість, економічність, науковість, ефективність }\end{array}$ \\
\hline Функції & Контрольна, забезпечувальна, захисна, аналітична, інформаційна \\
\hline
\end{tabular}




\begin{tabular}{|c|c|}
\hline 1 & 2 \\
\hline Завдання & 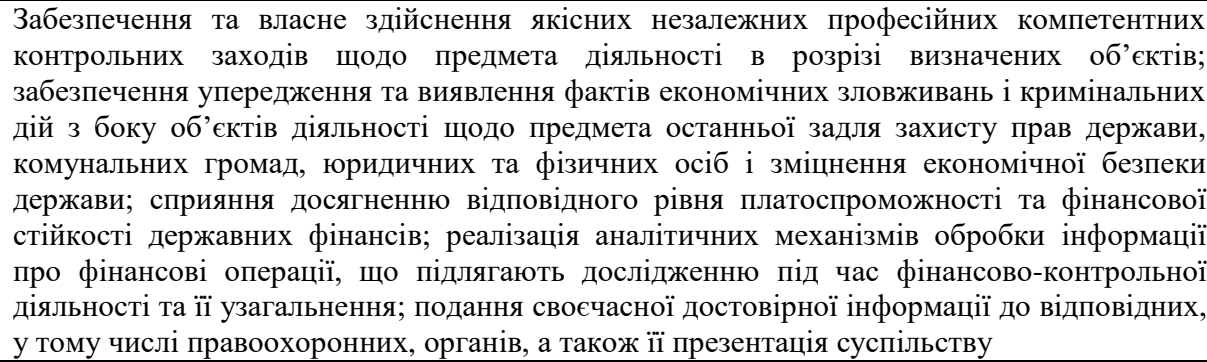 \\
\hline Форми & $\begin{array}{l}\text { Державний фінансовий контроль і аудит, податковий контроль, митний контроль, } \\
\text { казначейський контроль, фінансовий моніторинг та інші контрольні заходи }\end{array}$ \\
\hline Норми & $\begin{array}{l}\text { Конституція України і відповідні рішення Конституційного Суду, Бюджетний кодекс } \\
\text { України, Кодекс України про адміністративні правопорушення, Кримінальний кодекс } \\
\text { України, Податковий кодекс України, Митний кодекс України, Закон України «Про } \\
\text { Рахункову палату», Закон України «Про основні засади здійснення державного } \\
\text { фінансового контролю в Україні», Закон України «Про запобігання та протидію } \\
\text { легалізації (відмиванню) доходів, одержаних злочинним шляхом, фінансуванню } \\
\text { тероризму та фінансуванню розповсюдження зброї масового знищення», Укази } \\
\text { Президента, Постанови Кабінету Міністрів, Накази Міністерства фінансів України тощо }\end{array}$ \\
\hline
\end{tabular}

Представлені елементи такої матриці відображають вже ідентифіковані та систематизовані інституційні засади діяльності кожного конкретного іiі суб'єкта й одночасно презентують сформовані на їх базі фундаментальні положення державної фінансово-контрольної діяльності в контексті сприяння досягненню відповідного рівня бюджетної безпеки як інституціонального спрямування в загальному механізмі державного управління.

Висновки та перспективи подальших досліджень. Розбудова інституціональних засад державної фінансово-контрольної діяльності в контексті сприяння досягненню відповідного рівня бюджетної безпеки є важливим напрямом оздоровлення не тільки економіки нашого суспільства, а й його моральнодуховної сфери. Синергічний ефект таких зрушень забезпечить отримання реальних дієвих результатів на шляху реалізації Україною цілей сталого розвитку.

\section{Список використаної літератури:}

1. Про затвердження Методичних рекомендацій щодо розрахунку рівня економічної безпеки України : Наказ Міністерства економічного розвитку і торгівлі України від 29.10.2013 № 1277 [Електронний ресурс] Режим доступу : https://zakon.rada.gov.ua/rada/show/v1277731-13.

2. Степанюк Р.Л. Типові технології злочинності в бюджетній сфері / Р.Л. Степанюк // Форум права. - 2011. № 1. - C. 977-981.

3. Харко Д.М. Кримінологічні проблеми щодо визначення поняття та ознак сучасної економічної злочинності як фактора тінізації економіки України / Д.М. Харко [Електронний ресурс]. - Режим доступу: http://www.apdp.in.ua/v55/119.pdf.

4. Сатерленд Эдвин X. Являются ли преступления людей в белых воротничках преступлениями? Социология преступности. Современные буржуазные теории : сб. статей / Эдвин Х. Сатерленд. - Москва : Прогресс, 1966. $-368 \mathrm{c}$.

5. Головкін Б.М. Поняття злочинності у сфері економіки / Б.М. Головкін // Форум права. - 2013. - № 3.C. 128-133 [Електронний ресурс]. - Режим доступу : http://nbuv.gov.ua/UJRN/FP_index.

6. Стельмах С.П. Інституціоналізація історичної науки / С.П. Стельмах // Енциклопедія історії України / Редкол. : В.А. Смолій (голова) та ін. - Т. 3: Е-Й. - НАН України. Інститут історії України. - К. : Наукова думка, 2005. $-672 \mathrm{c}$.

7. Про Рахункову палату : Закон України від 02.07.2015 № 576-VIII [Електронний ресурс]. - Режим доступу : http://zakon1.rada.gov.ua/laws/show/576-19.

8. Конституція України : Закон України від 28.06.1996 № 254к/96-ВР [Електронний ресурс]. - Режим доступу : https://zakon.rada.gov.ua/laws/ show/254\%D0\%BA/96-\%D0\%B2\%D1\%80.

9. Бюджетний кодекс України [Електронний ресурс]. - Режим доступу : https://zakon.rada.gov.ua/laws/show/2456-17.

10. Кримінальний кодекс України [Електронний ресурс]. - Режим доступу : https://zakon.rada.gov.ua/laws/show/234114\#Text.

11. Грищишен Д.О. Архітектоника адаптивної моделі діяльності рахункової палати України / Д.О. Грищищен, С.В. Свірко, I.М. Яремчук. - Ефективна економіка. - 2018. - № 11 [Електронний ресурс]. - Режим доступу : http://www.economy.nayka.com.ua/pdf/11_2018/20.pdf.

12. Про затвердження Положення про Міністерство фінансів України : Постанова КМУ № 375 від 20.08.14 [Електронний ресурс]. - Режим доступу : https://zakon.rada.gov.ua/laws/show/375-2014-п\#Text. 
13. Про затвердження положення про Державну аудиторську службу України : Постанова КМУ № 43 від 03.02.16 [Електронний ресурс]. - Режим доступу : https://zakon.rada.gov.ua/laws/show/43-2016-п\#Text.

14. Про основні засади здійснення державного фінансового контролю в Україні : Закон України № 2939-XII від 26.01.93 [Електронний ресурс]. - Режим доступу : https://zakon.rada.gov.ua/laws/show/2939-12.

15. Про затвердження Положення про Державну податкову службу України та Державну митну службу України : Постанова КМУ № 227 від 06.03.19 [Електронний ресурс]. - Режим доступу : https://zakon.rada.gov.ua/laws/show/227-2019-п\#n15.

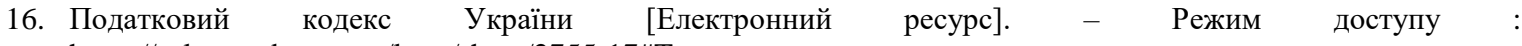
https://zakon.rada.gov.ua/laws/show/2755-17\#Text

17. Митний кодекс України [Електронний ресурс]. - Режим доступу : https://zakon.rada.gov.ua/laws/show/449517\#Text.

18. Про затвердження положення про Державну казначейську службу України : Постанова КМУ № 215 від 15.04.15 [Електронний ресурс]. - Режим доступу : https://zakon.rada.gov.ua/laws/show/215-2015-п\#Text.

19. Порядок реєстрації та обліку бюджетних зобов'язань розпорядників бюджетних коштів та одержувачів бюджетних коштів в органах Державної казначейської служби України : Наказ Міністерства фінансів України від 02.03.2012 № 309 [Електронний ресурс]. - Режим доступу : https://zakon.rada.gov.ua/laws/show/z0419-12.

20. Євдокимов B.B. Бухгалтерський облік в секторі загального державного управління України : підручник / В.В. Свдокимов, Д.О. Грищишен, С.В. Свірко. - Т. 1: Бухгалтерський облік в бюджетних установах України. - Житомир : Видавець О.О. Свенок, 2017. - 1380 с.

21. Порядок казначейського обслуговування місцевих бюджетів, затвердженого : Наказ Міністерства фінансів України від 23.08.2012 № 938 [Електронний ресурс]. - Режим доступу : https://zakon.rada.gov.ua/laws/show/z1569-12.

22. Порядок казначейського обслуговування державного бюджету за витратами : Наказ Міністерства фінансів України від 24.12.2012 № 1407 [Електронний ресурс]. - Режим доступу : https://zakon.rada.gov.ua/laws/show/z0130-13.

23. Про затвердження Положення про Державну службу фінансового моніторингу України : Постанова КМУ № 537 від 29.07.15 [Електронний ресурс]. - Режим доступу : https://zakon.rada.gov.ua/laws/show/537-2015-п\#Text.

24. Про запобігання та протидію легалізації (відмиванню) доходів, одержаних злочинним шляхом, фінансуванню тероризму та фінансуванню розповсюдження зброї масового знищення : Закон України № 361-IX від 06.12.19 [Електронний ресурc]. - Режим доступу : https://zakon.rada.gov.ua/laws/show/361-20\#n831.

25. Орехова I.C. Принципи державного контролю господарської діяльності / I.C. Орехова // Форум права. 2009. - № 2. - С. 309-315 [Електронний ресурс]. - Режим доступу : http://nbuv.gov.ua/UJRN/FP_index.

26. Фінансове право : підручник / за заг. ред. О.М. Бандурки та Ф59 О.П. Гетманець; Ю.М. Жорнокуй, О.В. Кашкарьова, Т.В. Колесник та ін. - Х. : Екограф, 2015 - 500 с.

27. Грищишен Д.О. Державна політика в сфері запобіганння та продидії кономічній злочинності : дис. ... д.держ.упр. : спец. 25.00.05 / Д.О. Грищишен. - Х., 2021. - 424 с. [Електронний ресурс]. - Режим доступу : https://nuczu.edu.ua/images/topmenu/science/spetsializovani-vcheni-rady/disHrytsyshen.pdf.

\section{References.}

1. Order of Ministry of Economic Development and Trade of Ukraine "About the statement of Methodical recommendations concerning calculation of the level of economic safety of Ukraine» (2013), No. 1277, [Online], available at: https://zakon.rada.gov.ua/rada/show/v1277731-13

2. Stepanjuk, R.L. (2011), «Typical technologies of crime in the budget sphere», Forum prava, No. 1, pp. 977-981.

3. Harko, D.M. (2010), «Criminological problems in defining the concept and designation of modern economic crime as a factor in shading the economy of Ukraine», [Online], available at: http://www.apdp.in.ua/v55/119.pdf

4. Saterlend, Edvin Kh. (1966), Yavlyayutsya li prestupleniya lyudei v belykh vorotnichkakh prestupleniyami? Sotsiologiya prestupnosti. Sovremennye burzhuaznye teorii, sb. Statei, Progress, Moskva, 368 p.

5. Golovkin, B.M. (2013), «The concept of crime in the field of economics», Forum prava, No. 3, pp. 128-133, [Online], available at: http://nbuv.gov.ua/UJRN/FP_index

6. Stel'mah, S.P. (2005), «Institutionalization of historical science», Encyclopedia of the History of Ukraine, in Smolij, V.A. (golova) et al. (ed.), Vol. 3: E-J, NAN Ukrai'ny, Instytut istorii' Ukrai'ny, Naukova dumka, Kyiv, Ukraine, $672 \mathrm{p}$.

7. The Law of Ukraine "About the Accounting Chamber» (2015), No. 576-VIII, [Online], available at: http://zakon1.rada.gov.ua/laws/show/576-19

8. The Law of Ukraine "Constitution of Ukraine» (1996), No. 254к/96-BP, [Online], available at: https://zakon.rada.gov.ua/laws/ show/254\%D0\%BA/96-\%D0\%B2\%D1\%80

9. Budget Code of Ukraine (2010), [Online], available at: https://zakon.rada.gov.ua/laws/show/2456-17

10. Criminal Code of Ukraine (2001), [Online], available at: https://zakon.rada.gov.ua/laws/show/2341-14\#Text

11. Grycyshen, D.O., Svirko, S.V. and Jaremchuk, I.M. (2018), «Architectonics of the adaptive model of activity of the Accounting Chamber of Ukraine», Efektyvna ekonomika, No. 11, [Online], available at: http://www.economy.nayka.com.ua/pdf/11_2018/20.pdf

12. Order of the Cabinet of Ministers of Ukraine «On approval of the Regulations on the Ministry of Finance of Ukraine» (2014), No. 375, [Online], available at: https://zakon.rada.gov.ua/laws/show/375-2014-n\#Text

13. Order of the Cabinet of Ministers of Ukraine "On approval of the regulations on the State Audit Service of Ukraine» (2016), No. 43, [Online], available at: https://zakon.rada.gov.ua/laws/show/43-2016-п\#Text 
14. The Law of Ukraine «On the basic principles of public financial control in Ukraine» (1993), No. 2939-XII, [Online], available at: https://zakon.rada.gov.ua/laws/show/2939-12

15. Order of the Cabinet of Ministers of Ukraine «On approval of the Regulations on the State Tax Service of Ukraine and the State Customs Service of Ukraine» (2016), No. 227, [Online], available at: https://zakon.rada.gov.ua/laws/show/227-2019-п\#n15

16. The Tax Code of Ukraine (2010), [Online], available at: https://zakon.rada.gov.ua/laws/show/2755-17\#Text

17. The Customs Code of Ukraine (2012), [Online], available at: https://zakon.rada.gov.ua/laws/show/4495-17\#Text

18. Order of the Cabinet of Ministers of Ukraine "On approval of the regulations on the State Treasury Service of Ukraine» (2015), No. 215, [Online], available at: https://zakon.rada.gov.ua/laws/show/215-2015-п\#Text

19. Order of the Ministry of Finance of Ukraine «Procedure for registration and accounting of budget obligations of budget managers and recipients of budget funds in the authorities of the State Treasury Service of Ukraine» (2012), No. 309, [Online], available at: https://zakon.rada.gov.ua/laws/show/z0419-12

20. Jevdokymov, V.V., Grycyshen, D.O. and Svirko, S.V. (2017), Buhgalters'kyj oblik v sektori zagal'nogo derzhavnogo upravlinnja Ukrai'ny, pidruchnyk, Vol. 1: Buhgalters'kyj oblik v bjudzhetnyh ustanovah Ukrai'ny, Vydavec' O.O. Jevenok, Zhytomyr, $1380 \mathrm{p}$.

21. Order of the Ministry of Finance of Ukraine «The order of treasury service of local budgets» (2012), No. 938, [Online], available at: https://zakon.rada.gov.ua/laws/show/z1569-12

22. Order of the Ministry of Finance of Ukraine «The order of treasury servicing of the state budget by expenses» (2012), No. 1407, [Online], available at: https://zakon.rada.gov.ua/laws/show/z0130-13

23. Order of the Cabinet of Ministers of Ukraine «On approval of the Regulations on the State Financial Monitoring Service of Ukraine» (2015), No. 537, [Online], available at: https://zakon.rada.gov.ua/laws/show/537-2015-п\#Text

24. The Law of Ukraine «On prevention and counteraction to legalization (laundering) of proceeds from crime, financing of terrorism and financing of proliferation of weapons of mass destruction» (2019), No. 361-IX, [Online], available at: https://zakon.rada.gov.ua/laws/show/361-20\#n831

25. Orehova, I.S. (2009), «Principles of state control of economic activity», Forum prava, No. 2, pp. 309-315, [Online], available at: http://nbuv.gov.ua/UJRN/FP_index

26. Bandurka, O.M. and F59 Getmanec', O.P., Zhornokuyj, Ju.M., Kashkar'ova, O.V., Kolesnyk T.V. et al. (ed.) (2015), Finansove pravo, pidruchnyk, Ekograf, H., 500 p.

27. Grycyshen, D.O. (2021), «State policy in the field of prevention and prevention of economic crime», D.Sc. Thesis of dissertation, spec. 25.00.05, H., $424 \quad$ p., [Online], available at: https://nuczu.edu.ua/images/topmenu/science/spetsializovani-vcheni-rady/disHrytsyshen.pdf

Грицишен Димитрій Олександрович - доктор економічних наук, професор, заслужений економіст України, декан факультету публічного управління та права Державного університету «Житомирська політехніка».

https://orcid.org/0000-0001-5484-6421.

Наукові інтереси: реалізація державної кримінальної політики у сфері запобігання та протидії економічній злочинності; оцінювання безпеки України як середовища поширення економічної злочинності.

E-mail: gritsishen.do@gmail.com.

Свірко Світлана Володимирівна - доктор економічних наук, професор, професор кафедри економічної безпеки, публічного управління та адміністрування Державного університету «Житомирська політехніка».

https://orcid.org/0000-0001-9157-4672.

Наукові інтереси: публічне управління; бюджетна безпека, бюджетна система; державні фінанси, система управління державними фінансами.

Супрунова Ірина Валеріївна - кандидат економічних наук, доцент, доцент кафедри економічної безпеки, публічного управління та адміністрування Державного університету «Житомирська політехніка». https://orcid.org/0000-0002-5800-3023.

Наукові інтереси: проблеми оцінки в бухгалтерському обліку; теорія, методологія та організація бухгалтерського обліку в секторі загального державного управління; державна політика у сфері детінізації національної економіки як структурної складової державної безпеки. 